\title{
Effect of Land tenure change on Land use in Machakos County, Kenya
}

\author{
Baaru. M.W, ${ }^{a, *}$, Gachene C.K.K ${ }^{\mathrm{b}}$ \\ ${ }^{a}$ Kenyatta University, baaru.mary@ku.ac.ke \\ ${ }^{b}$ University of Nairobi, gachene@uonbi.ac.ke \\ * Baaru.M.W, Phone: +254 722267 824, P.O BOX 43844-00100, Nairobi, Kenya
}

Keywords: Land use change, Land subdivision, Human settlement, Land tenure

\section{Abstract:}

Land tenure is considered an important issue of development agenda and this has led to land allocation and titling in developing countries across continents. As a result, a massive transfer of land rights. Land tenure has been considered as one of the key factors that define patterns and changes in land use system. Due to challenges in collective ownership, Kenya has embraced this idea shifted away to individual land tenure system. This paper examines how land tenure change has influenced land use patterns in Katheka-kai Location, Machakos County for 21 years (19882009), Kenya.

The study area was until 1995 a ranching scheme but transformed to individual farms, providing a niche in studying land use change. Six classes identified as forests, cultivated land, savannah grassland, water bodies, built-up land, rocky areas, and bare land was used for change detection. Thematic change detection for Landsat TM and Landsat ETM+ was established using ENVI EX. This was done by selecting two images of the same scene, with same number of classes and same names at different times.

During the period of 1988 - 2009, the major land use/cover was savannah grassland, bare land, rocky areas, and forest. Cultivated land, built-up areas, and water bodies had the least land cover. The land use/cover change has been dynamic with about $68.6 \%$ land changing from one land use to another between 1988 and 2009 (Figure 1 and 2).

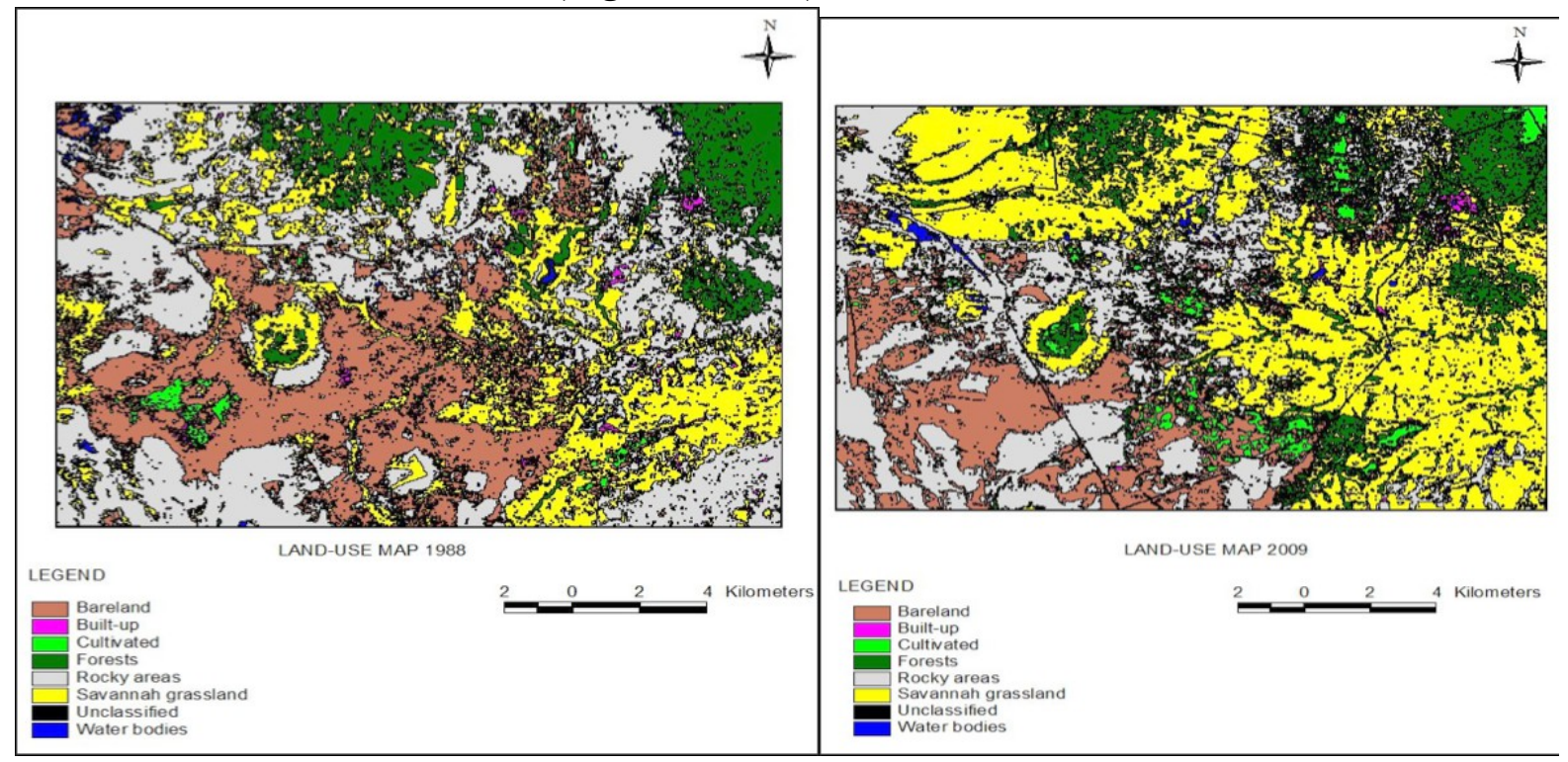

Figure 1: Land use/cover 1988

2009

Figure 2: Land use/cover 
The $24.4 \%$ increase recorded in savanna grassland was at the expense of rocky areas, forest cover, bareland and water bodies that lost 18.7, 2.9, 2.1 and $0.7 \%$ respectively (Table 1). Despite the loss, forest cover still recorded $2.7 \%$ increase between 1988 and 2009 mostly from rocky areas (1.6\%) and bare land (1.2\%). Apart from becoming savanna grassland, most of the bare land was converted to rocky areas (7.6\%), cultivated land $(1.8 \%)$ and forests (1.2\%) and this explains the $7.4 \%$ decrease in area under bareland. Cultivated land witnessed a 1.8\% increase between 1988 and 2009 and was due to conversion of bare land (1.8\%) and forest cover $(0.6 \%)$ into cultivated land. Increase in percentage area under built-up areas $(0.5 \%)$ was as result of conversion of bare land $(0.2 \%)$, rocky areas $(0.2 \%)$ and savanna grassland $(0.1 \%)$. Water bodies changed to become savanna grassland (0.7\%) and rocky areas $(0.4 \%)$ and this led to $0.5 \%$ decline in land under water bodies.

\begin{tabular}{|c|c|c|c|c|c|c|c|c|c|c|c|}
\hline \multicolumn{12}{|c|}{$\%$ Land use/cover transformed to other land use/cover } \\
\hline \multirow[t]{8}{*}{$\begin{array}{c}\% \\
\text { result } \\
\text { ant } \\
\text { land } \\
\text { use }\end{array}$} & \begin{tabular}{|l} 
Land \\
use/cov \\
er
\end{tabular} & $\begin{array}{l}\text { Savan } \\
\text { na } \\
\text { grassl } \\
\text { and }\end{array}$ & $\begin{array}{l}\text { Bare } \\
\text { land }\end{array}$ & $\begin{array}{l}\text { Built } \\
\text {-up }\end{array}$ & $\begin{array}{l}\text { Rocky } \\
\text { areas }\end{array}$ & $\begin{array}{l}\text { Cultivat } \\
\text { ed land }\end{array}$ & $\begin{array}{l}\text { Fore } \\
\text { sts }\end{array}$ & $\begin{array}{l}\text { Wate } \\
r \\
\text { bodie } \\
s\end{array}$ & $\begin{array}{l}2009 \\
\% \text { land } \\
\text { use/co } \\
\text { ver }\end{array}$ & $\begin{array}{l}2009 \% \\
\text { unchang } \\
\text { ed land } \\
\text { use }\end{array}$ & $\begin{array}{l}\text { \% } \\
\text { Tot } \\
\text { al } \\
\text { gai } \\
\text { n }\end{array}$ \\
\hline & $\begin{array}{l}\text { Savann } \\
\text { a } \\
\text { grasslan } \\
\text { d }\end{array}$ & 15.6 & 2.1 & 0.0 & 18.7 & 0.0 & 2.9 & 0.7 & 40.0 & 15.6 & $\begin{array}{l}24 . \\
4\end{array}$ \\
\hline & $\begin{array}{l}\text { Bare } \\
\text { land }\end{array}$ & 2.0 & 10.2 & 0.0 & 2.8 & 0.7 & 0.0 & 0.0 & 15.7 & 10.2 & 5.5 \\
\hline & Built-up & 0.1 & 0.2 & 0.1 & 0.2 & 0.0 & 0.0 & 0.0 & 0.6 & 0.1 & 0.5 \\
\hline & $\begin{array}{l}\text { Rocky } \\
\text { areas }\end{array}$ & 2.9 & 7.6 & 0.0 & 15.7 & 0.0 & 0.1 & 0.4 & 26.7 & 15.7 & $\begin{array}{l}11 . \\
0\end{array}$ \\
\hline & $\begin{array}{l}\text { Cultivate } \\
\text { d land }\end{array}$ & 0.0 & 1.8 & 0.0 & 0.1 & 0.2 & 0.6 & 0.0 & 2.8 & 0.2 & 2.6 \\
\hline & Forests & 3.5 & 1.2 & 0.0 & 1.6 & 0.1 & 0.6 & 0.0 & 6.9 & 0.6 & 6.3 \\
\hline & $\begin{array}{l}\text { Water } \\
\text { bodies }\end{array}$ & 0.1 & 0.0 & 0.0 & 0.5 & 0.0 & 0.0 & 0.0 & 0.6 & 0.0 & 0.6 \\
\hline $\begin{array}{l}1988- \\
\% \\
\text { land } \\
\text { use/c } \\
\text { over }\end{array}$ & & 24.2 & 23.1 & 0.1 & 39.5 & 1.0 & 4.2 & 1.1 & & & \\
\hline $\begin{array}{l}1988- \\
\% \\
\text { uncha } \\
\text { nged } \\
\text { land } \\
\text { use/c } \\
\text { over }\end{array}$ & & 15.6 & 10.2 & 0.1 & 15.7 & 0.2 & 0.6 & 0.0 & & & \\
\hline $\begin{array}{l}\text { Total } \\
\text { loss }\end{array}$ & & 8.6 & 12.9 & 0.0 & 23.8 & 0.8 & 3.6 & 1.1 & & & \\
\hline
\end{tabular}

Table 1: Percentage land use/ cover converted to other land uses between year 1988 and 2009 In all land use/cover, percentage land affected exceeded the unchanged land. The most affected land uses include rocky areas (34.7\%), savanna grassland (33.0\%), bare land $(18.3 \%)$ and forests (9.9\%). Percentage unchanged land was less than that affected in all 
land uses (Figure 3). However, all land under water bodies was affected. Apart from savanna grassland, cultivated land and forest cover that had gained more than was lost, all other land uses lost more land compared to what was gained.

\section{Figure 3: Land use/cover dynamics}

Savanna grassland, bare land and rocky areas are the dominating land uses/justified by the fact that the area is a rangeland initially hosting a range of wildlife animals. Increased population leads to high demand for food and housing and this explains the increase cultivation land and built-up areas.

A study carried out by Gathaara et. al. (2010) in the same area reported that most of the farmers resulted in agricultural activities to meet increasing food demand as well as for economic gains. Similarly, Mundia and Muranyan (2009) reported that changing land tenure policy resulted in expansion of agricultural land. Furthermore, after subdivision and issuance of title deeds to individual members, the owner gets the rights to make land use decisions based on benefits

\section{References}

Gathaara.V.N., Gachene C.K., Ngugi J.N., Thuranira E.G., Kilambya D.W., Baaru M.W. (2010). Adoption and opportunities for improving soil and water conservation practices in Kathekakai settlement scheme, Machakos District. Kenya Agricultural
Research Institute (KARI), Nairobi, Kenya.

Mundia CN., Murayama Y. (2009). Analysis of land use/cover changes and animal population dynamic in a wildlife sanctuary in East Africa. Journal.Remote Sens. 1, 952-970 